\title{
Neraca kehidupan kutukebul Bemisia tabaci (Gennadius) (Hemiptera: Aleyrodidae) pada tanaman cabai dan gulma babadotan pada suhu $25^{\circ} \mathrm{C}$ dan $29^{\circ} \mathrm{C}$
}

\author{
Life table of the silverleaf whitefly, Bemisia tabaci (Gennadius) \\ (Hemiptera: Aleyrodidae) on chili pepper and goatweed \\ at temperatures $25^{\circ} \mathrm{C}$ and $29^{\circ} \mathrm{C}$ \\ Vani Nur Oktaviany Subagyo, Purnama Hidayat* \\ Departemen Proteksi Tanaman, Fakultas Pertanian, Institut Pertanian Bogor \\ Jalan Kamper, Kampus IPB Darmaga, Bogor 16680
}

(diterima Juli 2013, disetujui Januari 2014)

\begin{abstract}
ABSTRAK
Bemisia tabaci (Gennadius) merupakan hama penting pada tanaman hortikultura. Selain dapat mengakibatkan kerusakan langsung pada tanaman, $B$. tabaci juga berperan sebagai vektor virus tanaman yang menyebabkan penyakit keriting kuning pada tanaman cabai. B. tabaci juga dapat menyerang gulma yang tumbuh di sekitar pertanaman cabai, diantaranya adalah Ageratum conyzoides atau gulma babadotan. Tujuan penelitian ini adalah untuk mempelajari neraca kehidupan B. tabaci pada tanaman cabai dan gulma babadotan. Percobaan dilakukan dengan mengamati 50 telur yang dipelihara pada masing-masing tanaman uji (3 ulangan). Tanaman ditumbuhkan pada suhu $25^{\circ} \mathrm{C}$ dan $29{ }^{\circ} \mathrm{C}$ di dalam growth chamber dengan pencahayaan 12 jam terang dan 12 jam gelap $(\mathrm{L}: \mathrm{D}=12: 12)$. Hasil analisis neraca kehidupan pada suhu $25^{\circ} \mathrm{C}$ dan $29^{\circ} \mathrm{C}$ menunjukkan bahwa $B$. tabaci memiliki laju reproduksi bersih $\left(\mathrm{R}_{0}\right)$, laju pertambahan intrinsik (r) dan keperidian lebih tinggi pada gulma babadotan dibandingkan dengan tanaman cabai. Oleh karena itu, keberadaan gulma babadotan di sekitar pertanaman cabai perlu diwaspadai, karena dapat menjadi inang yang baik bagi perkembangan $B$. tabaci.
\end{abstract}

Kata kunci: Bemisia tabaci, gulma babadotan, neraca kehidupan, tanaman cabai

\begin{abstract}
Bemisia tabaci (Gennadius) is an important pest on horticultural crops that can also become a vector of Geminivirus that transmit the yellow curl disease. $B$. tabaci can also attack weeds that grow around the field such as Ageratum conyzoides or goatweed. The objective of this research was to study the life cycle, life time, fecundity, and reproduction rate of $B$. tabaci on chili pepper and goatweed. The experiment was conducted by observing the development of 50 eggs into adulthood. All 50 eggs were put on one plant and repeated 3 times. The plants were grown at temperatures 25 ${ }^{\circ} \mathrm{C}$ and $29{ }^{\circ} \mathrm{C}$ inside growth chamber $(\mathrm{L}: \mathrm{D}=12: 12)$. The result of this experiments showed that at both temperatures of $25^{\circ} \mathrm{C}$ and $29^{\circ} \mathrm{C}$, reproductive rate $\left(\mathrm{R}_{0}\right)$, intrinsic rate of increase (r) and fecundity of $B$. tabaci were higher on goatweed than chili pepper. This implies that the existence of goatweed around chili pepper in the field can serve as a good alternative host for B. tabaci, hereby supporting the pest population even further.
\end{abstract}

Key words: Bemisia tabaci, chili, goatweed, life table

\footnotetext{
*Penulis korespondensi: Purnama Hidayat. Departemen Proteksi Tanaman, Fakultas Pertanian, Institut Pertanian Bogor, 


\section{PENDAHULUAN}

Bemisia tabaci (Gennadius) merupakan salah satu spesies kutukebul yang berperan sebagai hama penting pada berbagai tanaman pertanian (Simala et al. 2009). Selain itu, B. tabaci juga memiliki kemampuan sebagai vektor Tomato yellow leaf curl virus (TYLCV) yang umumnya menyerang pertanaman cabai di Indonesia (Ghanim et al. 2001; Sudiono 2003; Polston et al. 2006; Sudiono \& Yasin 2006). Kerusakan akibat TYLCV pada pertanaman cabai dapat menyebabkan kehilangan hasil panen 20\% sampai 100\% (Sudiono 2003; Sudiono \& Yasin 2006; Setiawati et al. 2007). B. tabaci juga menyerang berbagai jenis gulma yang tumbuh di sekitar pertanaman cabai. Salah satu spesies gulma yang paling banyak diserang adalah Ageratum conyzoides (Linnaeus) (Asterales: Asteraceae) atau lebih dikenal dengan nama gulma babadotan (Hendrival 2010). Menurut Meliansyah (2010), terdapat tiga belas jenis spesies gulma yang sudah terinfeksi Geminivirus di Pulau Jawa.

Penyebaran dan perkembangan $B$. tabaci pada berbagai tanaman didukung oleh kemampuan tingkat reproduksinya yang tinggi dan beberapa faktor lainnya yang dapat menyebabkan terjadinya dinamika populasi, seperti tanaman inang dan suhu (Naranjo \& Ellsworth 2005; Huang et al. 2008; Regniere et al.2012). Menurut Naranjo \& Ellsworth (2005), tanaman inang dapat mempengaruhi aspek biologi dan kelangsungan hidup suatu organisme dan berdasarkan hasil penelitian Kurniawan (2007), B. tabaci memiliki waktu generasi lebih cepat pada tanaman mentimun daripada tanaman cabai. Selain itu, menurut Huang et al. (2008), siklus hidup serangga juga akan lebih cepat seiring dengan meningkatnya suhu dan hasil penelitian Purbosari (2008), juga memperlihatkan bahwa siklus hidup imago B. tabaci pada suhu $29^{\circ} \mathrm{C}$ lebih cepat dibandingkan dengan pada suhu ruang dan suhu $23{ }^{\circ} \mathrm{C}$. Oleh kerena itu, informasi mengenai neraca kehidupan $B$. tabaci pada berbagai tanaman dan pada beberapa tingkatan suhu yang berbeda sangat diperlukan sebagai informasi dasar dalam menelaah perubahan kepadatan dan laju pertumbuhan atau penurunan populasi $B$. tabaci tersebut, yang hasilnya dapat berguna sebagai bahan pertimbangan tindakan pengendalian serangga ini di lapangan.
Tujuan penelitian ini adalah untuk menganalisis neraca kehidupan $B$. tabaci pada tanaman cabai dan gulma babadotan dengan dua tingkatan suhu yang berbeda, yaitu suhu $25^{\circ} \mathrm{C}$ dan $29^{\circ} \mathrm{C}$. Suhu $25{ }^{\circ} \mathrm{C}$ dipilih untuk mewakili daerah dataran sedang, sedangkan suhu $29{ }^{\circ} \mathrm{C}$ dipilih untuk mewakili daerah dataran rendah. Hal ini dilakukan untuk memperlihatkan pengaruh perbedaan tanaman inang dan suhu terhadap perkembangan dan pertumbuhan B. tabaci.

\section{BAHAN DAN METODE}

\section{Tempat dan waktu penelitian}

Penelitian dilaksanakan di Laboratorium Biosistematika Serangga, Departemen Proteksi Tanaman, Fakultas Pertanian, Institut Pertanian Bogor dari bulan Februari 2010 sampai Juli 2010.

\section{Persiapan pengujian}

Perbanyakan serangga. Perbanyakan diawali dengan menginvestasikan imago atau pupa $B$. tabaci dari lapangan ke dalam kurungan serangga, dengan tanaman tomat dan kapas sebagai inangnya. Setelah satu bulan populasi imago B. tabaci dalam kurungan digunakan sebagai bahan pengujian.

Persiapan tanaman uji. Tanaman yang digunakan dalam pengujian adalah tanaman cabai varietas Keriting Bogor umur tiga bulan dan gulma babadotan umur satu bulan. Pemilihan jenis tanaman uji didasarkan pada jenis tanaman yang umumnya banyak diserang $B$. tabaci dan dapat menjadi inang utama atau alternatif $B$. tabaci di lapangan, sedangkan pemilihan umur tanaman di dasarkan pada kesiapan tanaman untuk diujikan, yaitu tanaman tidak terlalu muda tetapi juga belum berbunga. Budi daya tanaman tidak menggunakan bahan kimia yang dapat meningkatkan ketahanan tanaman terhadap hama.

\section{Pengujian neraca kehidupan}

Pengujian neraca kehidupan pada tanaman diawali dengan memasukkan 15 individu imago B. tabaci (5 jantan dan 10 betina) ke dalam tabung plastik mika berbentuk silinder yang bagian atasnya dilapisi kain kasa dan pada bagian tengahnya terdapat lubang yang berfungsi untuk 
memasukkan imago tersebut dan setelah 24 jam, imago dikeluarkan dari tabung.

Setiap tanaman uji terdiri dari 3 ulangan dan banyaknya telur yang diamati pada setiap ulangan adalah 50 telur, sisa telur pada setiap ulangan dimatikan dengan cara ditusuk menggunakan jarum. Sehingga total populasi awal pada setiap jenis tanaman uji dalam suatu suhu adalah 150 telur.

Imago yang dihasilkan dari telur tersebut dipindahkan ke tanaman lain yang sama dengan inang sebelumnya, setiap kurungan hanya berisi satu imago (baik jantan maupun betina). Pengujian dilakukan pada suhu $25^{\circ} \mathrm{C}$ dan $29^{\circ} \mathrm{C}$ di dalam growth chamber merk SANYO model MLR-350H $(\mathrm{L}: \mathrm{D}=12: 12)$.

\section{Parameter neraca kehidupan}

Siklus hidup, lama hidup, dan keperidian dihitung menggunakan software SPSS 15 dengan uji Duncan taraf 5\%. Laju reproduksi dihitung berdasarkan parameter demografi menurut Birch (1948), meliputi:

1. Laju reproduksi bersih $\left(\mathrm{R}_{0}\right)$, dihitung dengan persamaan:

$$
\mathrm{R}_{0}=\Sigma \mathrm{l}_{\mathrm{x}} \mathrm{m}_{\mathrm{x}}
$$

2. Laju pertambahan intrinsik (r), dihitung dengan persamaan:

$$
\mathrm{r}=\ln \mathrm{R}_{0} / \mathrm{T}
$$

3. Rataan masa generasi $(\mathrm{T})$, dihitung dengan persamaan:

$$
\mathrm{T}=\Sigma \mathrm{x} \mathrm{l}_{\mathrm{x}} \mathrm{m}_{\mathrm{x}} / \Sigma \mathrm{l}_{\mathrm{x}} \mathrm{m}_{\mathrm{x}}
$$

4. Populasi berlipat ganda (DT), dihitung dengan persamaan:

$$
\mathrm{DT}=\ln (2) / \mathrm{r}
$$

dengan $\mathrm{x}$ : kelas umur kohort (hari); $1_{\mathrm{x}}$ : proporsi individu yang hidup pada umur ke-x; dan $\mathrm{m}_{\mathrm{x}}$ : keperidian spesifik individu pada kelas umur ke- $\mathrm{x}$.

Sementara itu, peubah biologi yang diamati adalah lama waktu perkembangan yang dibutuhkan sejak telur diletakkan oleh imago betina sampai menetas menjadi nimfa instar satu, lama waktu perkembangan yang dibutuhkan nimfa instar satu sampai menjadi pupa, lama waktu perkembangan yang dibutuhkan pupa sampai menjadi imago, lama hidup imago sejak keluar dari pupa sampai mati, masa sebelum peletakkan telur sampai meletakkan telur pertama kali (prapeneluran), dan jumlah telur yang diletakkan imago betina.

\section{HASIL}

\section{Siklus hidup}

Siklus hidup B. tabaci pada suhu $25{ }^{\circ} \mathrm{C}$ lebih singkat 3,79 hari pada gulma babadotan dibandingkan dengan pada tanaman cabai, sedangkan pada suhu $29^{\circ} \mathrm{C}$ lebih singkat 1,63 hari pada tanaman cabai dibandingkan dengan pada gulma babadotan (Tabel 1). Hasil penelitian juga memperlihatkan adanya penurunan lamanya siklus hidup seiring peningkatan suhu pada tanaman cabai sebesar 3,92 hari, tetapi penurunan ini tidak terjadi pada gulma babadotan yang mengalami penurunan kondisi secara fisik (mengeringnya beberapa helai daun bagian bawah) pada suhu $29^{\circ} \mathrm{C}$, sehingga siklus hidup $B$. tabaci pada gulma babadotan mengalami peningkatan 1,5 hari seiring meningkatnya suhu perlakuan.

\section{Lama hidup}

Lama hidup B. tabaci pada suhu $25{ }^{\circ} \mathrm{C}$ lebih singkat 3,13 hari pada gulma babadotan dibandingkan dengan pada tanaman cabai, sedangkan pada suhu $29^{\circ} \mathrm{C}$ lebih singkat 2,04 hari pada tanaman cabai dibandingkan dengan pada gulma babadotan (Tabel 1). Hasil pengamatan juga menunjukkan bahwa peningkatan suhu akan mempersingkat lama hidup B. tabaci pada tanaman cabai sebesar 4,21 hari, tetapi penurunan lama hidup seiring peningkatan suhu tidak terjadi

\begin{tabular}{|c|c|c|c|c|}
\hline \multirow{2}{*}{ Parameter populasi } & \multicolumn{2}{|c|}{$25^{\circ} \mathrm{C}$} & \multicolumn{2}{|c|}{$29^{\circ} \mathrm{C}$} \\
\hline & Cabai & Babadotan & Cabai & Babadotan \\
\hline Siklus hidup (hari) & $24,96 \pm 2,22 b$ & $21,17 \pm 1,61 \mathrm{a}$ & $21,04 \pm 0,91 \mathrm{a}$ & $22,67 \pm 1,01 \mathrm{~b}$ \\
\hline Lama hidup (hari) & $31,21 \pm 3,79 b$ & $28,08 \pm 3,51 \mathrm{a}$ & $27,00 \pm 2,62 \mathrm{a}$ & $29,04 \pm 1,68 b$ \\
\hline Keperidian (butir telur) & $37,71 \pm 18,11 \mathrm{a}$ & $48,50 \pm 17,01 \mathrm{~b}$ & $31,96 \pm 10,65 \mathrm{a}$ & $43,83 \pm 9,64 b$ \\
\hline
\end{tabular}
pada gulma babadotan. Lama hidup B. tabaci pada

Tabel 1. Siklus hidup, lama hidup, dan keperidian Bemisia tabaci pada suhu $25^{\circ} \mathrm{C}$ dan $29^{\circ} \mathrm{C}$ pada tanaman cabai dan gulma babadotan

Angka-angka pada baris yang sama dan suhu yang sama serta diikuti oleh huruf yang sama menunjukkan hasil yang tidak berbeda nyata berdasarkan uji selang berganda Duncan pada taraf $\alpha=5 \%$. 
gulma babadotan pada suhu $25{ }^{\circ} \mathrm{C}$ lebih singkat 0,96 hari dibandingkan dengan pada suhu $29^{\circ} \mathrm{C}$.

\section{Keperidian}

Keperidian imago betina $B$. tabaci pada suhu $25{ }^{\circ} \mathrm{C}$ pada tanaman cabai dan gulma babadotan secara berurutan adalah 37,71 dan 48,50 butir telur (Tabel 1). Puncak nilai $\mathrm{m}_{\mathrm{x}}$ pada tanaman cabai terjadi pada hari ke-25 dengan rata-rata 6,53 butir telur per satu individu betina, sedangkan puncak nilai $m_{x}$ pada gulma babadotan terjadi pada hari ke-22 dengan rata-rata 8,34 butir telur per satu individu betina (Gambar 1a dan 2a). Sementara itu, keperidian imago betina $B$. tabaci pada suhu $29{ }^{\circ} \mathrm{C}$ pada tanaman cabai dan gulma babadotan secara berurutan adalah 31,96 dan 43,83 butir telur (Tabel 1). Puncak nilai $m_{x}$ pada tanaman cabai terjadi pada hari ke-21 dengan rata-rata 6,89 butir telur per satu individu betina, sedangkan puncak nilai $\mathrm{m}_{\mathrm{x}}$ pada gulma babadotan terjadi pada hari ke-22 dengan rata-rata 7,80 butir telur per satu individu betina (Gambar 1b dan 2b).

Laju kematian B. tabaci pada suhu $25^{\circ} \mathrm{C}$ dan $29^{\circ} \mathrm{C}$ pada tanaman cabai dan gulma babadotan mulai terjadi pada stadia telur, yang ditunjukkan dengan penurunan jumlah telur pada hari ke-12 dan ke-9 pada suhu $25{ }^{\circ} \mathrm{C}$ (Gambar 1a dan 2a) dan pada hari ke-6 dan ke-12 pada suhu $29{ }^{\circ} \mathrm{C}$ (Gambar 1b dan 2b). Persentase keberhasilan telur untuk menetas dapat dilihat dari data kematian pada stadia telur, dimana keberhasilan telur untuk menetas pada suhu $25{ }^{\circ} \mathrm{C}$ sebesar $98,67 \%$ pada gulma babadotan, sedangkan pada tanaman cabai sebesar 99,33\%. Sementara itu, persentase keberhasilan telur menetas pada suhu $29{ }^{\circ} \mathrm{C}$ pada tanaman cabai dan gulma babadotan secara berurutan sebesar $91,33 \%$ dan $94,67 \%$.

\section{Laju reproduksi}

Nilai $\mathrm{R}_{0}$ atau laju reproduksi bersih pada tanaman cabai dan gulma babadotan pada suhu $25{ }^{\circ} \mathrm{C}$ masing-masing adalah 28,94 dan 57,28 individu per induk per generasi. Pada suhu $29{ }^{\circ} \mathrm{C}$ nilai $\mathrm{R}_{0}$ pada tanaman cabai dan gulma babadotan secara berurutan adalah 15,77 dan 23,09 individu per induk per generasi. Hasil penelitian juga menunjukkan seiring peningkatan suhu dari $25^{\circ} \mathrm{C}$ ke $29{ }^{\circ} \mathrm{C}$ terjadi penurunan nilai $\mathrm{R}_{0}$ pada tanaman cabai dan gulma babadotan, secara berurutan nilainya adalah 13,17 dan 34,19 individu per induk per generasi (Tabel 2).

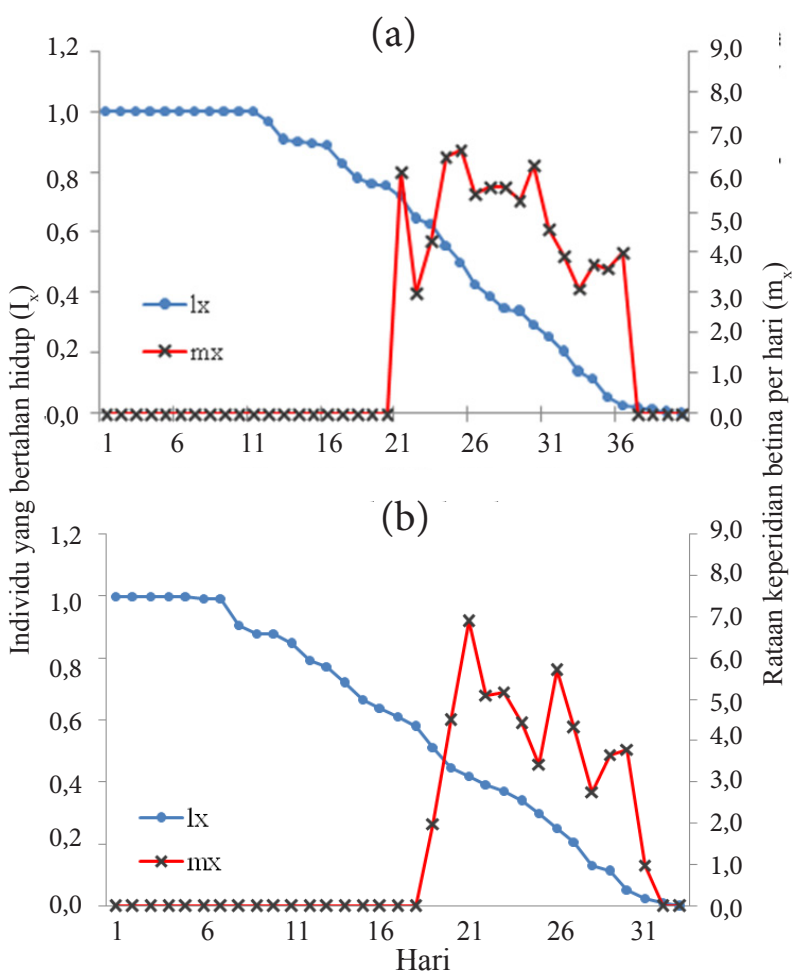

Gambar 1. Kurva individu Bemisia tabaci yang hidup pada umur ke-x $\left(1_{x}\right)$ dan rataan keperidian individu B. tabaci pada umur ke-x $\left(\mathrm{m}_{\mathrm{x}}\right)$ pada tanaman cabai pada suhu $25^{\circ} \mathrm{C}$ (a) dan $29^{\circ} \mathrm{C}$ (b).

(a)

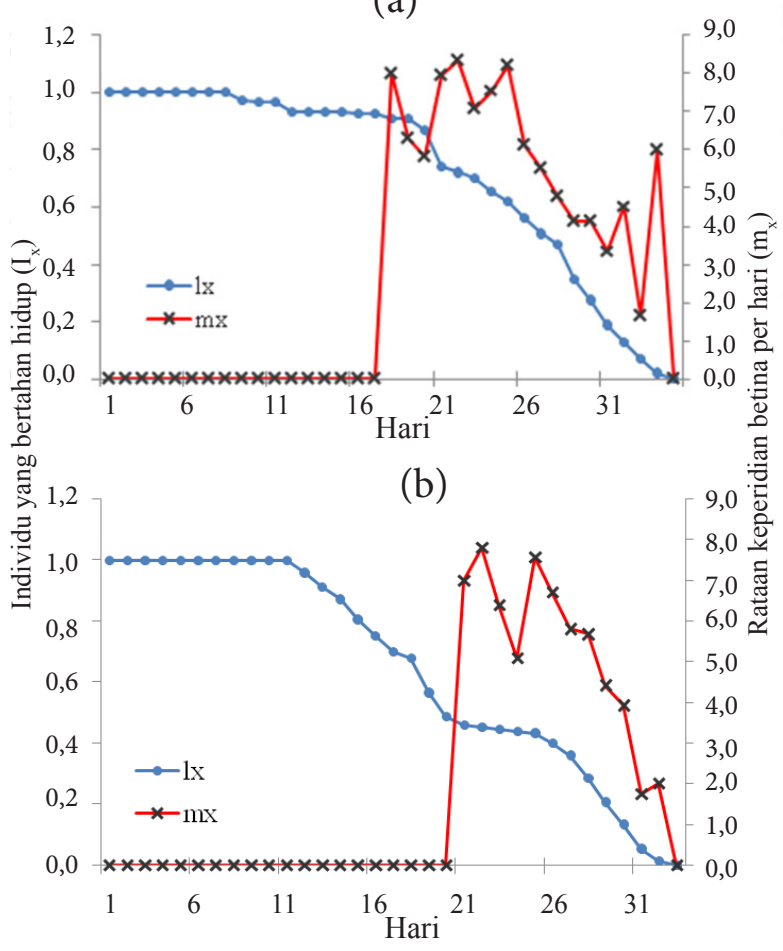

Gambar 2. Kurva individu Bemisia tabaci yang hidup pada umur ke-x $\left(1_{x}\right)$ dan rataan keperidian individu $B$. tabaci pada umur ke-x $\left(\mathrm{m}_{\mathrm{x}}\right)$ pada gulma babadotan pada suhu $25^{\circ} \mathrm{C}$ (a) dan $29^{\circ} \mathrm{C}$ (b). 
Nilai $\mathrm{r}$ B. tabaci pada suhu $25^{\circ} \mathrm{C}$ pada tanaman cabai dan gulma babadotan berturut-turut adalah 0,13 dan 0,18 individu per induk per hari. Pada suhu $29^{\circ} \mathrm{C}$ nilai $\mathrm{r}$ pada tanaman cabai dan gulma babadotan adalah 0,12 dan 0,13 individu per induk per hari. Nilai $r$ pada tanaman cabai dan gulma babadotan menurun seiring meningkatnya suhu, besarnya penurunan nilai $r$ secara berurutan adalah 0,1 dan 0,5 individu per induk per hari. Perbedaan nilai r ini disebabkan oleh adanya perbedaan tingkat kematian, kelahiran, dan waktu perkembangan B. tabaci pada masing-masing tanaman tersebut disetiap tahap pengujian (Tabel 2).

Rataan masa generasi B. tabaci pada suhu $25^{\circ} \mathrm{C}$ pada tanaman cabai dan gulma babadotan masingmasing adalah 25,68 dan 22,74 hari, sedangkan nilai T B. tabaci pada suhu $29^{\circ} \mathrm{C}$ pada tanaman cabai dan pada gulma babadotan secara berurutan adalah 22,97 dan 24,45 hari. Rataan masa generasi B. tabaci pada tanaman cabai seiring meningkatnya suhu mengalami penurunan 2,71 hari, sedangkan pada gulma babadotan seiring meningkatnya suhu masa generasi B. tabaci bertambah 1,71 hari (Tabel 2).

Waktu yang dibutuhkan $B$. tabaci untuk berlipat ganda (DT) pada suhu $25^{\circ} \mathrm{C}$ pada tanaman cabai dan gulma babadotan masing-masing adalah 5,33 dan 3,85 hari, sedangkan DT B. tabaci pada suhu $29^{\circ} \mathrm{C}$ pada tanaman cabai dan gulma babadotan secara berurutan adalah 5,78 dan 5,33 hari. Nilai DT pada tanaman cabai dan gulma babadotan mengalami peningkatan seiring dengan meningkatnya suhu dari $25{ }^{\circ} \mathrm{C}$ ke $29{ }^{\circ} \mathrm{C}$, secara berurutan adalah 0,45 dan 1,48 hari.

\section{PEMBAHASAN}

Perbedaan siklus hidup serangga dapat dipengaruhi oleh jenis spesies, tanaman inang, suhu, dan teknik perbanyakan serangga tersebut dan beberapa faktor dari tanaman yang dapat mempengaruhi serangga dalam proses pemilihan dan penentuan inang adalah bentuk daun, jumlah trikoma, serta senyawa kimia hasil proses metabolisme sekunder tanaman tersebut (Morgan et al. 2001; Schoonhoven et al. 2005). Secara umum, hasil penelitian ini menunjukkan bahwa siklus hidup $B$. tabaci lebih singkat pada gulma babadotan dibandingkan dengan pada tanaman cabai. Menurut Muniz (2000), B. tabaci memang memiliki kesesuaian hidup yang tinggi pada beberapa jenis gulma.

Faktor lainnya yang juga mempengaruhi siklus hidup B. tabaci adalah suhu, dimana semakin meningkatnya suhu maka siklus hidup serangga akan semakin singkat, tetapi pada suhu di atas $30{ }^{\circ} \mathrm{C}$ waktu yang diperlukan serangga untuk menyelesaikan siklus hidupnya pada umumnya akan lebih lama, karena kemampuan bertahan hidupnya menurun drastis (Wang \& Tsai 1996). Hal ini sesuai dengan hasil penelitian, dimana siklus hidup dan lama hidup B. tabaci pada tanaman cabai pada suhu $29^{\circ} \mathrm{C}$ lebih singkat dibandingkan dengan pada suhu $25{ }^{\circ} \mathrm{C}$. Namun, penurunan waktu siklus hidup dan lama hidup B. tabaci seiring dengan peningkatan suhu, tidak terjadi pada gulma babadotan. Hal ini disebabkan oleh, adanya penurunan kondisi gulma babadotan (daun mengering) yang berpengaruh pada perkembangan B. tabaci, karena kisaran suhu optimum bagi gulma babadotan itu sendiri menurut Moenandir (1988) adalah pada suhu $16^{\circ} \mathrm{C}$ sampai $24^{\circ} \mathrm{C}$.

Jumlah individu betina dalam suatu populasi dapat mempengaruhi nilai keperidian, sedangkan jumlah telur yang dihasilkan oleh imago betina dapat memperlihatkan tingkat kesesuaian individu pada tanaman inangnya (Wang \& Tsai 1996). Hasil penelitian menunjukkan bahwa pada kedua suhu pengujian keperidian B. tabaci lebih tinggi

Tabel 2. Neraca kehidupan Bemisia tabaci tanaman cabai dan gulma babadotan pada suhu $25^{\circ} \mathrm{C}$ dan $29^{\circ} \mathrm{C}$

\begin{tabular}{lrrrr}
\hline \multirow{2}{*}{ Parameter populasi } & \multicolumn{3}{c}{$25^{\circ} \mathrm{C}$} & \multicolumn{3}{c}{$29^{\circ} \mathrm{C}$} \\
\cline { 2 - 5 } & Cabai & Babadotan & Cabai & Babadotan \\
\hline $\mathrm{R}_{0}$ & 28,94 & 57,28 & 15,77 & 23,09 \\
$\mathrm{r}$ & 0,13 & 0,18 & 0,12 & 0,13 \\
$\mathrm{~T}$ & 25,68 & 22,74 & 22,97 & 24,45 \\
$\mathrm{DT}$ & 5,33 & 3,85 & 5,78 & 5,33 \\
\hline
\end{tabular}

$\mathrm{R}_{0}$ : laju reproduksi bersih (individu/induk/generasi); r: laju pertambahan intrinsik (individu/induk/hari); T: rataan masa generasi (hari); DT: waktu untuk populasi berlipat ganda (hari) 
pada gulma babadotan dibandingkan dengan pada tanaman cabai, selain itu seiring peningkatan suhu terjadi penurunan keperidian imago betina baik pada tanaman cabai maupun pada gulma babadotan. Hasil ini sejalan dengan hasil penelitian Purbosari (2008), yang menunjukkan bahwa keperidian imago betina $B$. tabaci pada suhu $23{ }^{\circ} \mathrm{C}$ lebih tinggi dibandingkan dengan pada suhu ruang dan suhu $29{ }^{\circ} \mathrm{C}$. Peningkatan suhu juga berpengaruh pada pergeseran kurva $m_{x}$, bergeser ke sebelah kiri seiring dengan peningkatan suhu, kecuali pada gulma babadotan yang memang mengalami penurunan kondisi secara fisik pada suhu $29^{\circ} \mathrm{C}$, sehingga hasilnya berdampak lain. Hal ini berarti, peningkatan suhu akan mempercepat waktu peneluran dan mempersingkat masa peneluran.

Laju reproduksi dapat menggambarkan kesesuaian tanaman inang bagi $B$. tabaci, karena hasil siklus hidup, lama hidup, dan keperidian belum bisa menggambarkan hal tersebut (Birch 1948). Nilai $R_{0}$ yang tinggi memperlihatkan tingkat kesesuian hidup B. tabaci pada suatu tanaman. Nilai $\mathrm{R}_{0}$ paling tinggi pada suhu $25^{\circ} \mathrm{C}$ dan $29{ }^{\circ} \mathrm{C}$ terdapat pada gulma babadotan sehingga dapat disimpulkan bahwa B. tabaci lebih sesuai hidup pada gulma babadotan dibandingkan dengan tanaman cabai. Penurunan nilai $\mathrm{R}_{0}$ yang tinggi pada gulma babadotan pada suhu $29{ }^{\circ} \mathrm{C}$ tidak akan merubah kesimpulan bahwa $B$. tabaci lebih sesuai hidup pada gulma babadotan pada suhu tersebut. Hal ini disebabkan oleh singkatnya waktu untuk populasi berlipat ganda (DT) pada gulma babadotan dibandingkan dengan pada tanaman cabai. Nilai DT yang tinggi akan meningkatkan nilai $\mathrm{R}_{0}$ dalam satuan waktu tertentu dan jika nilai $\mathrm{R}_{0}<1$ artinya populasi serangga akan menurun menuju kepunahan, sedangkan bila $\mathrm{R}_{0}>1$ artinya populasi serangga akan meningkat (Birch 1948).

Menurut Birch (1948), jika nilai r lebih kecil dari nilai $\mathrm{r}$ minimum artinya spesies tersebut gagal dalam bertahan hidup. Suatu populasi akan mencapai nilai $r$ yang tinggi apabila suatu individu mencapai fase dewasa dengan tingkat reproduksi yang lebih awal. Nilai $r$ tertinggi dari hasil pengujian terdapat pada gulma babadotan, baik pada suhu $25^{\circ} \mathrm{C}$ maupun pada suhu $29{ }^{\circ} \mathrm{C}$. Tingginya nilai $r$ ini disebabkan oleh tingginya keperidian, rendahnya mortalitas pradewasa dan masa dewasa B. tabaci pada gulma babadotan pada kedua suhu tersebut. Tetapi, nilai laju pertambahan intrinsik (r) yang tinggi pada suatu spesies tidak selalu diartikan sebagai tingkat keberhasilan dalam suatu habitat. Hal ini disebabkan oleh adanya proses seleksi dari spesies tersebut agar nilai $r$ nya menjadi relatif tinggi, sehingga dapat berkompetisi dengan spesies yang lain (Birch 1948).

Rataan masa generasi ( $\mathrm{T}$ ) adalah rataan waktu yang dibutuhkan sejak telur diletakkan hingga saat imago betina menghasilkan separuh keturunannya (Birch 1948). Spesies pada suatu populasi yang mempunyai nilai $\mathrm{T}$ yang rendah akan tumbuh lebih cepat dibandingkan dengan spesies pada populasi yang mempunyai nilai $\mathrm{T}$ yang tinggi dan dari hasil pengujian menunjukkan bahwa waktu yang dibutuhkan $B$. tabaci untuk menghasilkan separuh keturunannya pada gulma babadotan lebih singkat dibandingkan dengan pada tanaman cabai pada suhu $25{ }^{\circ} \mathrm{C}$, sedangkan pada suhu $29{ }^{\circ} \mathrm{C}$ adalah sebaliknya. Hal ini berarti, pada tanaman cabai populasi B. tabaci tumbuh lebih cepat pada suhu $29^{\circ} \mathrm{C}$ dibandingkan dengan pada suhu $25{ }^{\circ} \mathrm{C}$, sedangkan pada gulma babadotan populasi $B$. tabaci tumbuh lebih cepat pada suhu $25{ }^{\circ} \mathrm{C}$ dibandingkan dengan pada suhu $29{ }^{\circ} \mathrm{C}$. Walaupun demikian, kesesuaian inang tidak dapat digambarkan hanya dari nilai $\mathrm{T}$, karena nilai $\mathrm{R}_{0}, \mathrm{r}$, dan DT juga sangat berpengaruh.

Waktu yang dibutuhkan B. tabaci untuk berlipat ganda (DT) pada kedua suhu lebih singkat pada gulma babadotan dibandingkan dengan pada tanaman cabai. Menurut Birch (1948), nilai populasi berlipat ganda yang tinggi pada suatu individu dapat menyebabkan penurunan sumber daya lingkungan dan mempengaruhi nilai laju pertambahan intrinsik (r). Terlihat bahwa nilai DT yang tinggi pada suhu $29^{\circ} \mathrm{C}$, telah mempengaruhi penurunan nilai $\mathrm{r}$ dari suhu $25^{\circ} \mathrm{C}$ ke suhu $29^{\circ} \mathrm{C}$. Pertambahan individu dalam suatu populasi akan mengurangi sumberdaya pada lingkungan tersebut yang diasumsikan konstan. Sementara itu, peningkatan nilai DT seiring dengan peningkatan suhu pada kedua tanaman inang menunjukkan bahwa $B$. tabaci pada tanaman cabai dan gulma babadotan akan lebih cepat berlipat ganda pada suhu $25^{\circ} \mathrm{C}$. 


\section{KESIMPULAN}

Siklus hidup dan lama hidup B. tabaci pada suhu $25{ }^{\circ} \mathrm{C}$ lebih singkat pada gulma babadotan dibandingkan dengan pada tanaman cabai, sedangkan pada suhu $29{ }^{\circ} \mathrm{C}$ terjadi sebaliknya. Nilai keperidian B. tabaci pada gulma babadotan di kedua suhu pengujian lebih tinggi dibandingkan dengan pada tanaman cabai. Hasil laju reproduksi B. tabaci pada suhu $25^{\circ} \mathrm{C}$ dan $29^{\circ} \mathrm{C}$ menunjukkan bahwa $B$. tabaci lebih sesuai hidup pada gulma babadotan dibandingkan dengan pada tanaman cabai. Oleh karena itu, keberadaan gulma babadotan disekitar pertanaman cabai harus diwaspadai, karena dapat menjadi inang yang baik bagi perkembangan $B$. tabaci.

\section{DAFTAR PUSTAKA}

Birch LC. 1948. The intristic rate of natural increase of an insect population. The Journal of Animal Ecology 17:15-26.

Ghanim M, Morin S, Czosnek H. 2001. Rate of Tomato yellow leaf curl virus translocation in the circulative transmission pathway of its vector, the whitefly Bemisia tabaci. Phytopathology 91:188196.

Hendrival. 2010. Bemisia tabaci Genn. (Hemiptera: Aleyrodidae): Kisaran Inang, Dinamika Populasi, dan Kelimpahan Musuh Alami di Area Pertanaman Cabai Merah di Kecamatan Pakem Kabupaten Sleman Provinsi DIY. Master Thesis. Bogor: Institut Pertanian Bogor.

Huang Z, Ren S, Musa PD. 2008. Effects of temperature on development, survival, longevity, and fecundity of the Bemisia tabaci Gennadius (Homoptera: Aleyrodidae) predator, Axinoscymnus cardilobus (Coleoptera: Coccinellidae). Biological Control 46(2008): 209-215.

Kurniawan HA. 2007. Neraca Kehidupan Kutukebul Bemisia tabaci Gennadius (Hemiptera: Aleyrodidae) Biotipe-B dan Non-B pada Tanaman Mentimun (Curcumis sativus L.) dan Cabai (Capsicum annuum L.). Master Thesis. Bogor: Institut Pertanian Bogor.

Meliansyah R. 2010. Peranan Gulma sebagai Inang Alternatif Geminivirus di Pertanaman Cabai di Jawa. Master Tesis. Bogor: Institut Pertanian Bogor.
Moenandir J. 1988. Pengantar Ilmu dan Pengendalian Gulma. Jakarta: Rajawali Press.

Morgan D, Walters KFA, Aegerter JN. 2001. Effect of temperatur and cultivar on pea Aphid, Acyrthosiphon pisum (Hemiptera: Aphididae) life history. Bulletin of Entomological Research 91:47-52.

Muniz M. 2000. Host suitability of two biotypes of Bemisia tabaci on some common weeds. Entomologia Experimentalis et Applicata 95: 63-70.

Naranjo SE, Ellsworth PC. 2005. Mortality dinamics and population regulation in Bemisia tabaci. Entomologia Exsperimentalis et Applicata 116:93-108.

Polston JE, Cohen L, Sherwood TA, Ben JR, Lapidot M. 2006. Capsicum species: Symptomless hosts and reservoirs of Tomato yellow leaf curl virus. Phytopathology 96:447-452.

Purbosari S. 2008. Neraca Kehidupan Kutukebul, Bemisia tabaci Genn. (Hemiptera: Aleyrodidae) pada Suhu $23{ }^{\circ} \mathrm{C}$, Ruang, dan $29{ }^{\circ} \mathrm{C}$. Skripsi. Bogor: Institut Pertanian Bogor.

Regniere J, Powell J, Bentz B, Nealis V. 2012. Effects of temperature on development, survival and reproduction of insects: Experimental design, data analysis and modeling. Journal of Insect Physiology 58 (2012):634-647.

Schoonhoven LM, Loon JJA van, Dicke M. 2005. Insect Plant Biology. Oxford: Oxford University Press.

Setiawati W, Udiarto BK, Soetiarso TA. 2007. Selektivitas beberapa insektisida terhadap hama kutukebul (Bemisia tabaci Genn.) dan predator Menochilus sexmaculata. Jurnal Hortikultura 17:168-174.

Simala M, Milek TM, Koric B. 2009. Whitefly species (Hemiptera: Aleyrodidae) recorded on imported ornamental plants in Croatia from 2005-2008. In: Joze Macek (Ed.), Proceedings of the 9th International Symposium on Plant Protection; (Nova Gorica, 2009 March 4-5). pp. 389-396. Nova Gorica: Drustvo za Varstvo Rastlin Slovenije.

Sudiono. 2003. Deteksi symtomolgy dan teknik PCR virus gemini asal tanaman tomat. Jurnal Agritek 11:537-544

Sudiono, Yasin N. 2006. Karakteristik kutukebul (Bemisia tabaci) sebagai vektor virus gemini dengan teknik PCR-RAPD. Jurnal Hama dan Penyakit Tumbuhan Tropika 6:113-119.

Wang K, Tsai JH. 1996. Temperature effect on development and reproduction of silverleaf 
whitefly (Homoptera: Aleyrodidae). Annals of the

Entomological Society of America 89:573-579. 